\title{
Composition of EVs markers under normoxic and hypoxic conditions depends on the expression level of adaptor protein Ruk/CIN85 in mouse renal carcinoma Renca cells
}

\author{
A. Yu. Zhyvolozhnyi ${ }^{1,2}$, I. R. Horak ${ }^{2}$, T. D. Skaterna ${ }^{2}$, O. V. Khudiakova², S. J. Vainio ${ }^{1}$, \\ A. A. Samoylenko ${ }^{1}$, L. B. Drobot ${ }^{2}$ \\ ${ }^{1}$ University of Oulu \\ Linnanmaa, PO Box 3000, FIN-90014 Oulu, Finland \\ 2 Palladin Institute of Biochemistry, NAS of Ukraine \\ 9, Leontovycha Str., Kyiv, Ukraine, 01601 \\ ppndl2@gmail.com
}

\begin{abstract}
Aim. To isolate and characterize extracellular vesicles (EVs) produced by mouse renal carcinoma Renca cells with different expression levels of the adaptor protein Ruk/CIN85 under normoxia and hypoxia conditions. Methods. The density gradient centrifugation was used to isolate EVs from the conditioned medium of Renca cells cultured under normoxia and hypoxia conditions. Further characterization of EVs was performed by using nanoparticle tracking analysis (NTA), electron microscopy and Western Blot analysis. Results. Significant differences in average particle size between EVs produced by sublines studied under experimental conditions were not found. At the same time, concentration of particles produced by Ruk/ CIN85 overexpressing cells turned out to be an order of magnitude higher in hypoxia in comparison to normoxia conditions. It was shown that under normoxia conditions the content of both Ruk/CIN85 and EVs' markers Alix and CD81 was increased in vesicles produced by Renca cells with Ruk/CIN85 overexpression in comparison with those from control mocktransfected cells. Under hypoxia conditions, the content of studied proteins decreased by more than two orders of magnitude in EVs secreted by Renca cells with up-regulation of adaptor protein whereas the content of Ruk/CIN85 and CD81 increased in EVs from mock-transfected cells. Conclusions. It has been demonstrated that the adaptor protein Ruk/CIN85 is a novel component of EVs produced by tumor cells that may play a role in the control of EV composition under normoxia and hypoxia.
\end{abstract}

Keyword s: renal cell carcinoma, extracellular vesicles, exosomes, adaptor protein Ruk/ CIN85, normoxia, hypoxia.

(C) 2021 A. Yu. Zhyvolozhnyi et al.; Published by the Institute of Molecular Biology and Genetics, NAS of Ukraine on behalf of Biopolymers and Cell. This is an Open Access article distributed under the terms of the Creative Commons Attribution License (http://creativecommons.org/licenses/by/4.0/), which permits unrestricted reuse, distribution, and reproduction in any medium, provided the original work is properly cited 
One of the leading roles in intercellular communication is played by the transmission of signalling molecules through extracellular vesicles (EVs), formed by membrane exocytosis (microvesicles) or endocytosis with further release from multivesicular bodies (MVBs) (exosomes). Extracellular vesicle is a collective definition that covers different cell-released spherical structures covered with a membrane bilayer and enriched in number of biomolecules, including DNA, multiple types of RNA, various proteins and chemical metabolites [1]. Found in all body fluids (blood, urine, saliva, sweat, faeces etc.) [2-4], EVs are the source of information about a large number of processes and disorders at the cellular level. Currently, the attempts are made to use EVs for the detection and treatment of tumours [5], as well as a means of active specialized immunotherapy [6]. Due to a number of specific properties, EVs are considered the best substitute for artificial liposomes used in cancer treatment [7]. On the other hand, a correlation was found between the intensity of EVs production, their cargo composition and the metastatic potential of tumour cells [8]. Recently we have demonstrated the notable changes in the EVs production level and EVs cargo content in Renca cells under different conditions of culturing (hypoxia versus normoxia) $[9,10]$. Such EVs can be a potentially useful tool for monitoring stimuli-induced changes. The ability of EVs to suppress immunity, enhance tumour growth, and the development of resistance to antitumor drugs have been shown [11]. Renal cell carcinoma (RCC) is the most common malignancy of adult kidney characterized by the resistance to traditional radiotherapy and chemotherapy as well as a markedly high incidence of metastasis. In recent years, great progress was achieved in the diagnosis and treatment of RCC, especially by the introduction of novel agents that target vascular endothelial growth factor (VEGF) and the mammalian target of rapamycin [12]. Essential components of signaling networks are adaptor/scaffold proteins. They not only assemble the multimolecular complexes but also direct and coordinate intracellular signaling in order to fine-tune cellular behavior [13]. There are data that proteins Alix [14] and Tsg101 [15] involved in the formation of MVBs and currently recognized as marker proteins of sEVs, as well as cortactin $[16,17]$, which stimulates the secretion of sEVs, are the binding partners of SH3-containing adaptor protein Ruk/CIN85. Additionally, we have shown previously that up-regulation of Ruk/ CIN85 in the low invasive human breast adenocarcinoma MCF-7 cells is followed by their malignization [18]. Taking into account these data, in the current study we elucidated the features of biogenesis of EVs produced by mouse renal carcinoma Renca cells with different expression levels of Ruk/CIN85 under normoxia and hypoxia conditions as well as their marker proteins composition.

\section{Materials and Methods}

Cell culture and transfection. Mouse renal cell adenocarcinoma (RCC)-derived Renca cells (ATCC ${ }^{\circledR}$ CRL-2947TM) were cultured in DMEM medium (Gibco, 10567014) supplemented with $10 \%$ fetal bovine serum (FBS) (Gibco, 26140079), $100 \mu \mathrm{g} / \mathrm{ml}$ streptomycin, $100 \mathrm{U} / \mathrm{ml}$ penicillin in a humidified atmosphere containing $5 \% \mathrm{CO}_{2}$ at $37^{\circ} \mathrm{C} .1 \times 10^{6}$ cells per $10 \mathrm{~cm}$ dish (Greiner Cellstar, 664160) were 
plated for the experiments. To obtain the sublines with stable overexpression of full-length Ruk/CIN85 form, the RCC cells were transfected with the $\mathrm{pRc} / \mathrm{CMV} 2-\mathrm{Ruk}_{1}$ vector using calcium phosphate precipitation (with corresponding RCC Mock subline). Transfected cells were selected in the presence of antibiotic geneticin sulphate G418 $(1 \mathrm{mg} / \mathrm{ml})$ followed by subcloning. The selection of stable transfectants and their subcloning were carried out for two months.

EVs purification. Cultured RCC cells were kept under normoxia ( $21 \%$ oxygen) until $80 \%$ of confluence in standard medium and $10 \mathrm{~cm}$ culture dishes. Then the medium was changed for the medium without FBS and kept for 24 hours under normoxia ( $21 \%$ oxygen) or hypoxia ( $1 \%$ oxygen) conditions followed by medium collection. To remove debris, the collected medium was centrifuged at $5000 \mathrm{~g}$ for $10 \mathrm{~min}$. Debris free medium was concentrated by using Centricon Plus-70 filter units (Merck Millipore) for 15 minutes at $2500 \mathrm{~g}$. The EVs were purified from a concentrated medium (Normoxia/Hypoxia) via an Optiprep ${ }^{\text {TM}}$-based density gradient centrifugation procedure as described in [8]. After centrifugation, the pellet was resuspended in $300 \mu \mathrm{l}$ of PBS (Corning ${ }^{\mathrm{TM}}$ $21040 \mathrm{CM})$. Each fraction was analyzed via electron microscopy and nanoparticle tracking analysis (NTA). The fractions with the highest EVs content were used for the experiments.

NTA measurements. The EVs size ratio and particles concentration were measured via nanoparticle tracking analysis (NanoSight NM300, Malvern Panalytical). Before measurements, the samples were diluted 1:1000 in distilled water. Brownian motion of each sample was recorded four times (60-sec videos) with camera level 14 and detection threshold 3 . NTA software version 3.4 was used for data analysis.

Electron microscopy. All samples were analysed via transmission electron microscopy. Each EVs sample was located on a Formvar carbonated grid and stained with $2 \%$ uranyl acetate.

Western blot analysis. The cell lysates were prepared by adding $3 \mathrm{ml}$ of RIPA buffer solution (Sigma-Aldrich R0278) with the proteinase (Sigma P5726) and phosphatase (Roche 50892791001) inhibitors per one dish. After cell scratching, lysates were incubated for 30 min on a shacking platform at $+4{ }^{\circ} \mathrm{C}$ followed by centrifugation at $12000 \mathrm{~g}$. EVs samples were lyzed in RIPA buffer (Cell Signaling Technology) with phosphatase inhibitors (Sigma-Aldrich) and protease inhibitors (cOmplete $^{\mathrm{TM}}$ ULTRA Roche). Proteins (10 $\mu \mathrm{g}$ per sample) were separated via $10 \%$ SDS PAGE gel and transferred to the nitrocellulose membrane (Thermo Scientific ${ }^{\mathrm{TM}}$ 88018). The membranes were incubated overnight at $4{ }^{\circ} \mathrm{C}$ with anti-Ruk/CIN85 C-terminal antibodies $(1: 3000)$ [16], and antibodies against EVs markers CD81 (sc-166029, 1:1000) and ALIX (ab117600, 1:1000). Anti-alpha Tubulin (ab7291, 1:5000) antibodies were used as a loading control for cell lysates. The corresponding secondary IgG antibodies (Invitrogen) at 1:5000 dilutions were applied. For the visualization of bound secondary antibodies, the Lumi-Light Western Blotting Substrate (Roche Diagnostics, Switzerland) was used. Densitometric analysis was performed using the GelPro analyzer software (Media Cybernetics, http://gel-pro-analyzer.software.informer. $\operatorname{com} / 3.1 /)$. 


\section{Results and Discussion}

As demonstrated in the publication of Tossidou et al. [18], SH3-containing adaptor protein Ruk/CIN85 is a binding partner of nephrin and podocin that mediates slit diaphragm turnover in podocytes and proteinuria. High levels of Ruk/CIN85 expression were demonstrated in human tumors of different tissue origins that were correlated with the degree of their malignancy and advanced tu- mor stage [19-24]. To date, no similar information is available regarding renal carcinogenesis. In order to estimate the potential role of Ruk/CIN85 in renal cancer as well as in the control of EVs production and their protein composition, we generated stable subclones of mouse renal carcinoma Renca cells overexpressing adaptor protein and corresponding control Mock cells. According to the results of morphology and Western blot analysis, a stable

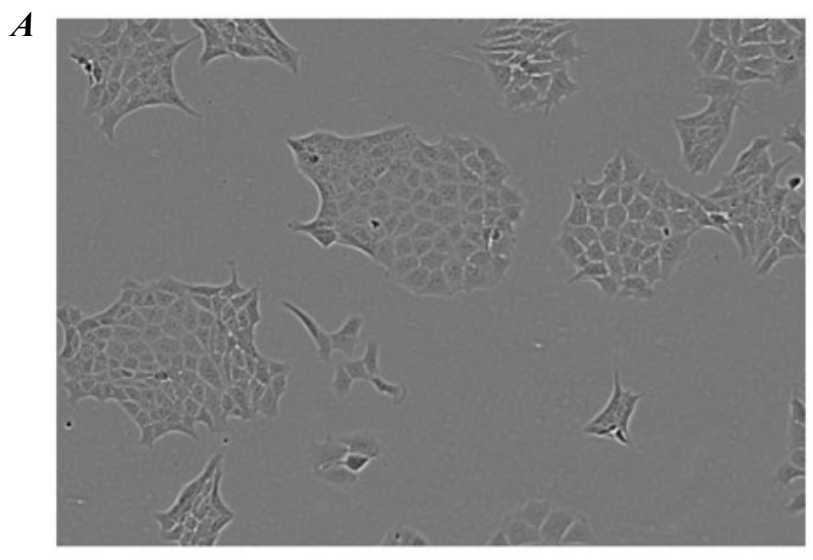

1

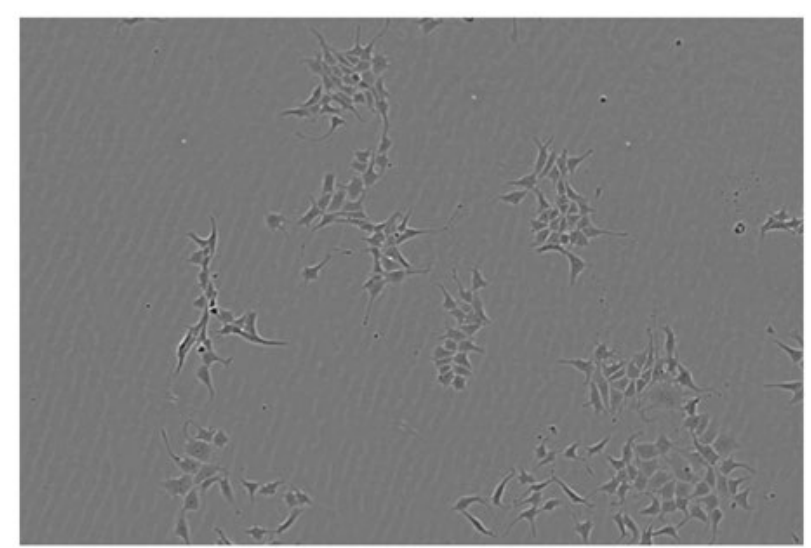

2

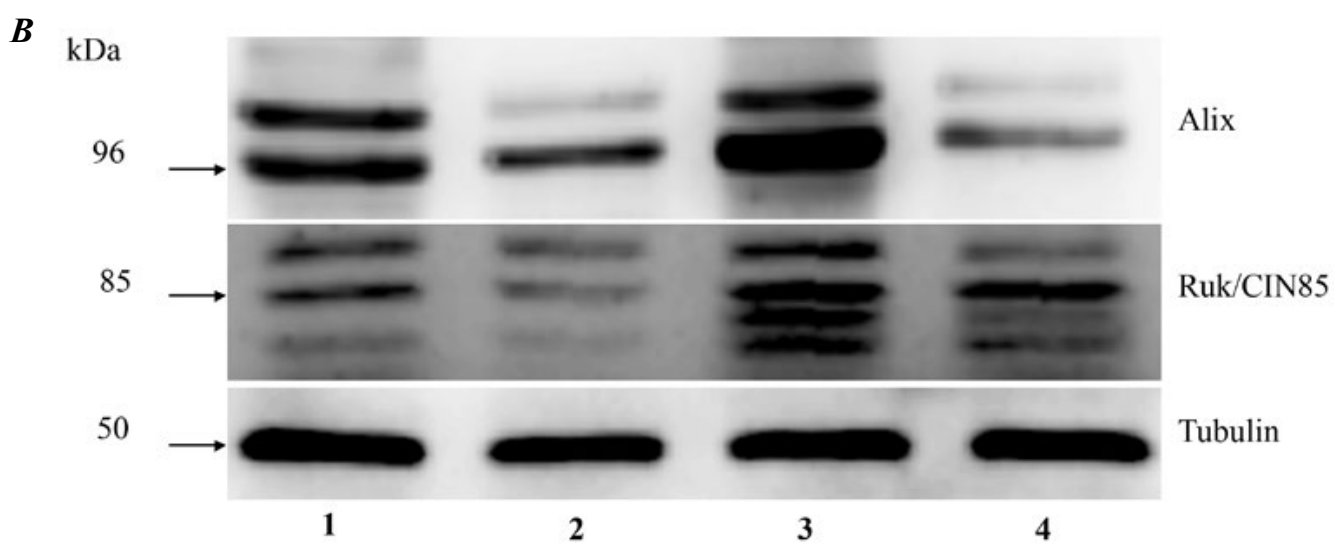

Fig. 1. The content of Ruk/CIN85 and the marker of EVs, Alix protein, in Mock and RukUp Renca cells decreased under hypoxic conditions. A. Microscopic images of Renca Mock cells (1) and Renca RukUp subclone (2). B. Western blot analysis of Ruk/CIN85 and Alix proteins: 1, 2 - Renca Mock; 3, 4 - Renca RukUp; 1, 3 - content of Ruk/ CIN85 and Alix in Renca cells under normoxia conditions; 2, 4 - content of Ruk/CIN85 and Alix in Renca cells under hypoxia. 
subclone of Renca RukUp cells was selected for further analysis (Fig.1 A, B). According to the data obtained, Mock cells revealed cobblestone-like phenotype exhibiting tight cell-cell contacts characteristic of epithelial cells whereas RukUp cells acquired mesenchymal phenotype represented by elongated cells with extensions of various lengths (Fig. $1 \mathrm{~A}$ ). As can be seen from Fig. $1 \mathrm{~B}$, the full-length $85 \mathrm{kDa}$ form of Ruk/CIN85 is detected as se- veral bands, which may be a result of posttranslational modification of this protein [19]. It was found that in both Mock and RukUp cells the content of Ruk/CIN85 decreases to different levels under hypoxic conditions, most significantly in overexpressing cells. Similar patterns of changes were demonstrated for the EVs marker protein, Alix. Noteworthy, the overexpression of Ruk/CIN85 in Renca cells is also accompanied by an increase in the

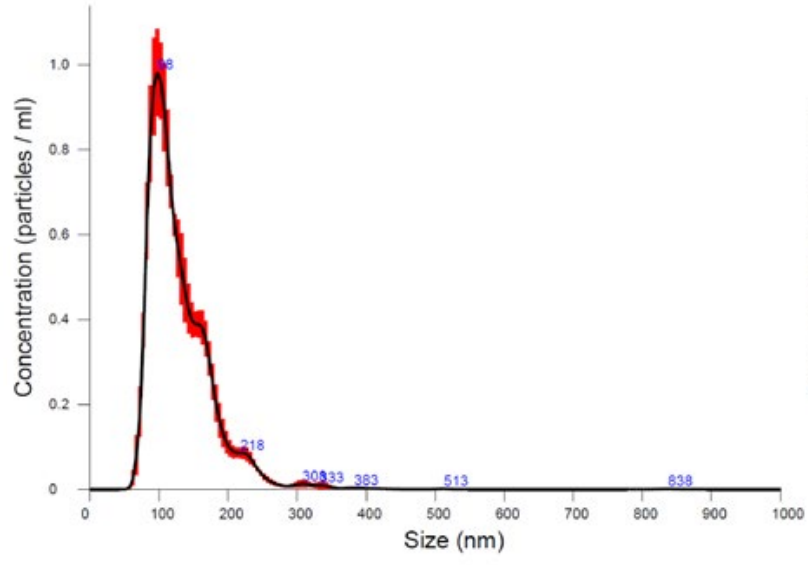

Renca Mock Normoxia

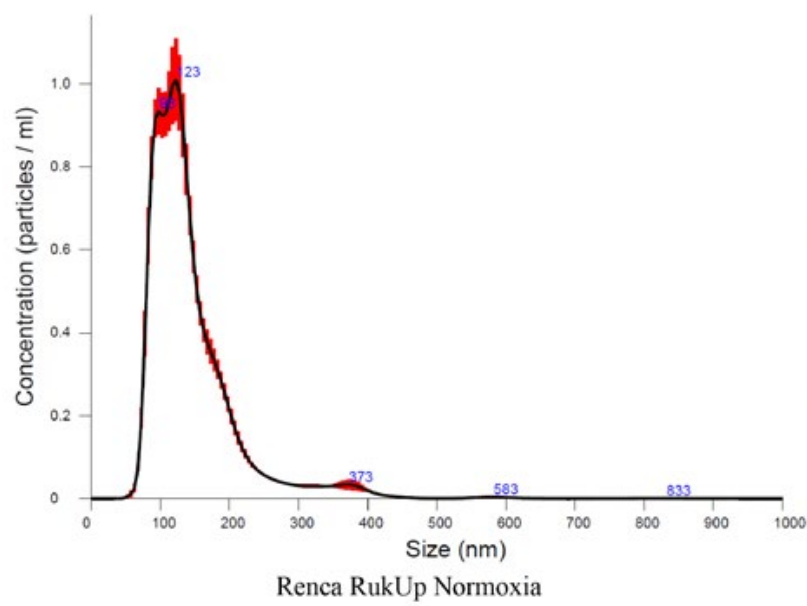

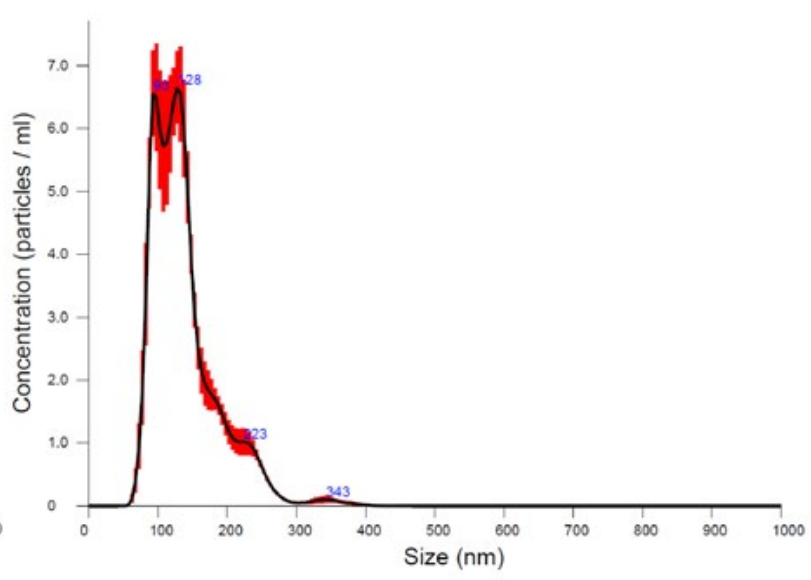

Renca Mock Hypoxia

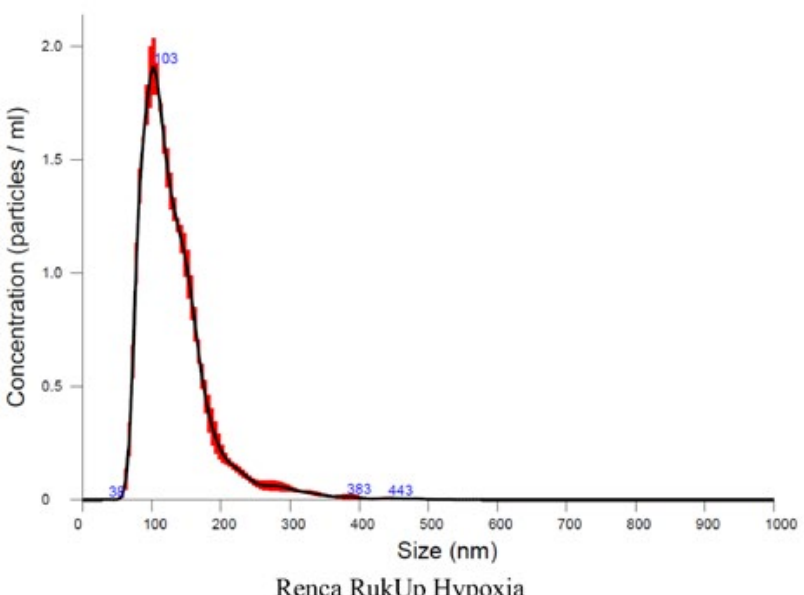

Renca RukUp Hypoxia

Fig. 2. The size distribution of nanoparticles in preparations of EVs isolated from Renca cells supernatants via NanoSight measurements. 
level of Alix expression, which is a characteristic feature of advanced tumors [25].

Both Ruk/CIN85 and the mammalian adaptor protein Alix [ALG-2 (apoptosis-linked gene-2 product)-interacting protein $\mathrm{X}]$ are involved in biogenesis of MVBs [26, 27]. Alix has at the C-termini PRD (proline-rich motif), which mediates the interactions through $\mathrm{SH} 3$ domains in partner proteins, including with Ruk/CIN85 [14]. The important finding is that Alix not only packages cargo to enter vesicles,

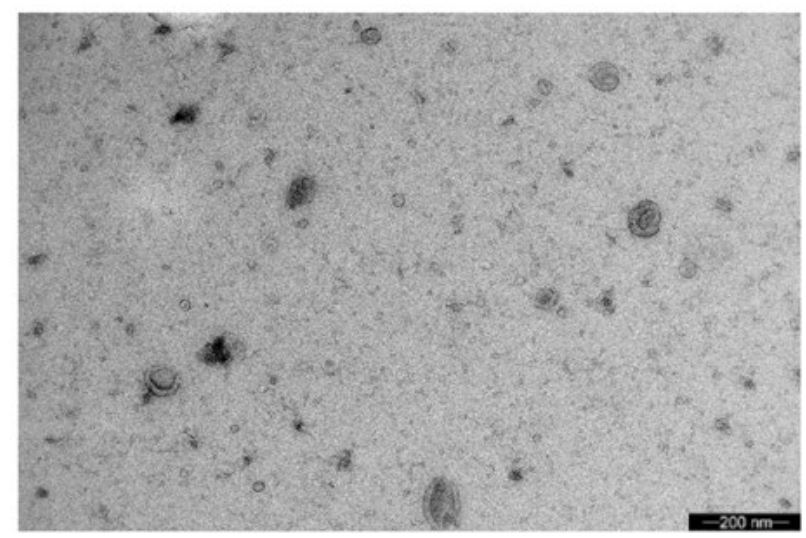

Renca Mock Normoxia

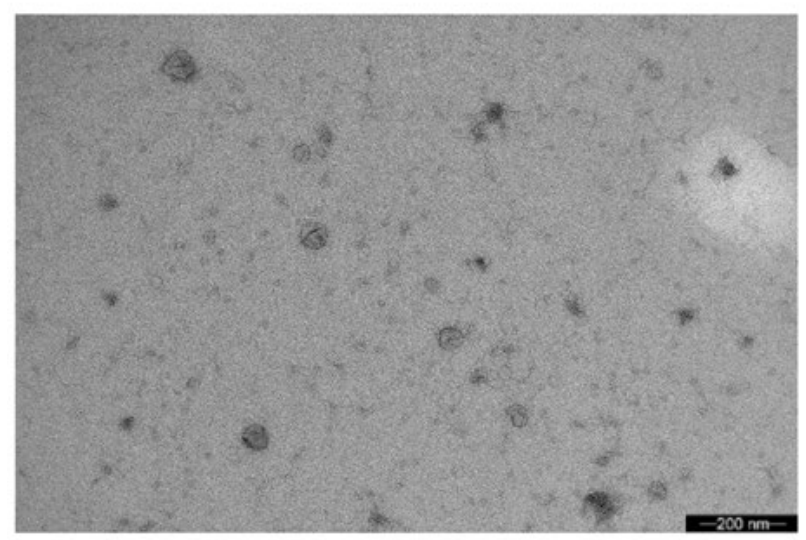

Renca RukUp Normoxia but also triggers vesicle formation [27]. Thus, it is likely that Ruk/CIN85 adaptor protein may also be a biologically relevant component of vesicles produced by Renca cells.

The number and size of nanoparticles in the selected preparations of EVs produced by Mock and RukUp Renca cells were analysed using NanoSight measurements. According to the results, we did not find statistically significant differences in the average size of particles in the isolated samples of EVs. At the

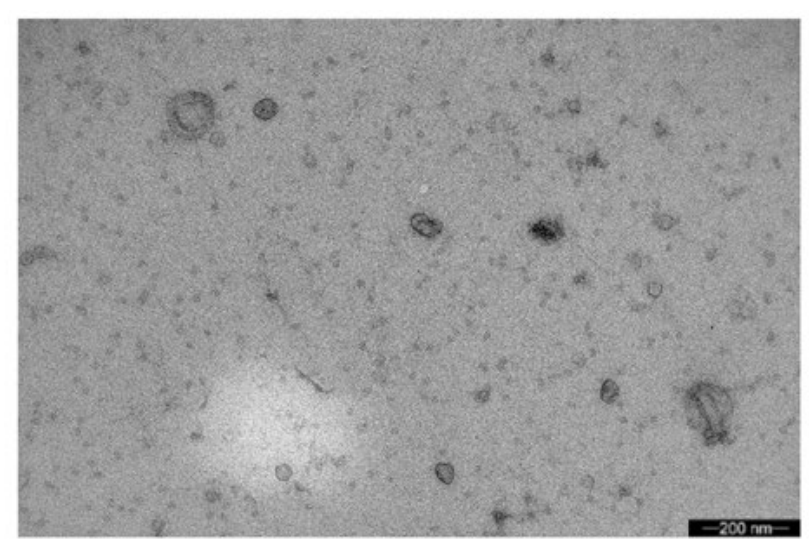

Renca Mock Hypoxia

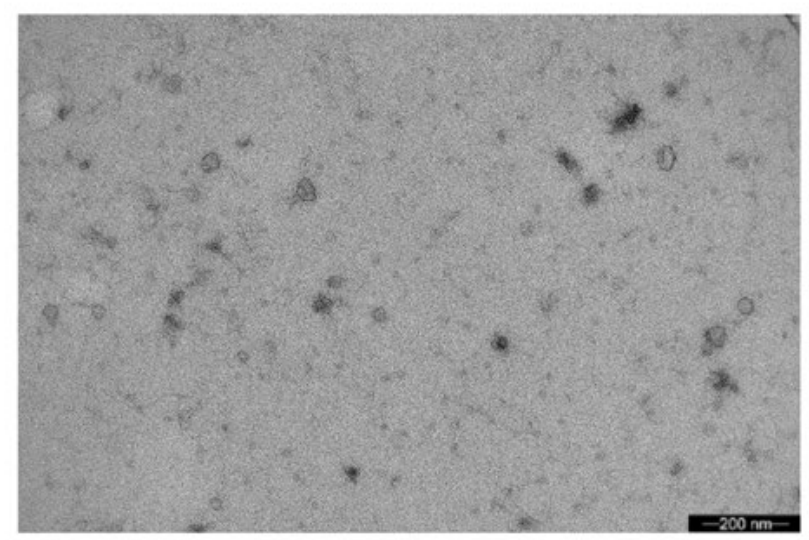

Renca RukUp Hypoxia

Fig. 3. Typical electron microscopic images of EVs isolated from the Renca cells supernatants under conditions of normoxia and hypoxia. 


\begin{tabular}{|l|c|c|}
\hline & Concentration & Average particle size \\
\hline Renca Mock N & $1.86^{*} 10^{11} / \mathrm{ml}+/-4.75^{*} 10^{10}$ particles $/ \mathrm{ml}$ & $137.9 \mathrm{~nm}$ \\
Renca Mock H & $3.13^{*} 10^{11} / \mathrm{ml}+/-4.84^{*} 10^{10}$ particles $/ \mathrm{ml}$ & $130.2 \mathrm{~nm}$ \\
Renca Ruk N & $1.16^{*} 10^{11} / \mathrm{ml}+/-4.88^{*} 10^{10}$ particles $/ \mathrm{ml}$ & $132.0 \mathrm{~nm}$ \\
Renca Ruk H & $1.42 * 10^{12} / \mathrm{ml}+/-2.62 * 10^{11}$ particles $/ \mathrm{ml}$ & $144.4 \mathrm{~nm}$
\end{tabular}

same time, the concentration of EVs produced by Renca control cells increased by approximately $40 \%$ under hypoxia compared to normoxia.

In contrast, the concentration of EVs isolated from supernatants of Renca cells with Ruk/CIN85 overexpression under hypoxia increased by an order of magnitude compared to both normoxia and control cells. The size ratio graphs of the data obtained with the NanoSight device are presented in Fig. 2, and typical electron microscopic photographs of EVs in Fig. 3.

The information on the particles concentration (considering the dilution factor) and average size obtained with NanoSight instrument is presented in Table.

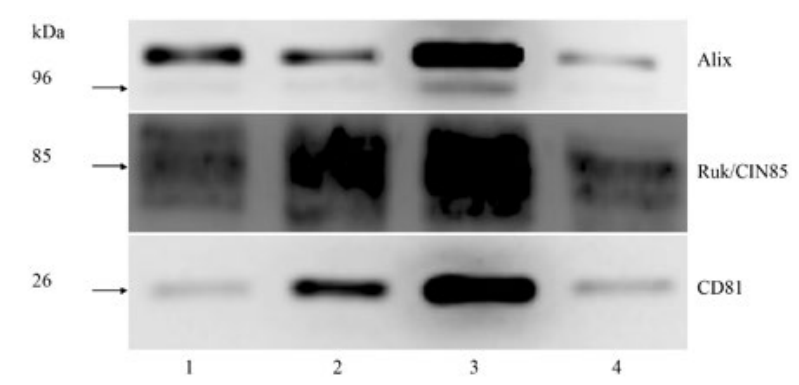

Fig. 4. The content of Ruk/CIN85 and markers of EVs, Alix and CD81 proteins, in EVs preparations isolated from the conditioned medium of Renca Mock $(1,2)$ and RukUp $(3,4)$ cells under conditions of normoxia $(1,3)$ and hypoxia $(2,4)$.
At the next stage, we examined the content of Ruk/CIN85 and EVs markers, Alix and CD81 proteins, in EVs preparations isolated from the conditioned medium of Renca Mock and RukUp cells under normoxia and hypoxia conditions. As can be seen from Fig. 4, the content of both Ruk/CIN85 and EVs markers Alix and CD81 significantly increased in EVs produced by Renca cells with Ruk/CIN85 overexpression under normoxia conditions and decreased under hypoxia conditions. Interestingly, in control cells, the content of Ruk/CIN85 and CD81 increased under hypoxia conditions, whereas Alix - decreased. These observations may indicate the involvement of Ruk/CIN85 in differential control of the EVs marker proteins composition under hypoxia depending on its expression level in cancer cells. It is also noteworthy that the vesicles accumulate a form of Alix protein, which moves more slowly in SDS-PAAG compared to the main $96 \mathrm{kDa}$ form and presumably represents a form modified by phosphorylation [28].

\section{Conclusions}

It was demonstrated that the adaptor protein Ruk/CIN85 is a newly identified component of EVs produced by tumor cells. Additionally, the potential role of Ruk/CIN85 in the control of EVs protein composition under conditions of normoxia and hypoxia was established. 


\section{Acknowledgements}

The study was supported by the EDUFI (Finnish National Agency for Education) fellowships to A. Yu. Zhyvolozhnyi.

\section{REFERENCES}

1. Théry C, Witwer K, Aikawa E, Alcaraz $M$ et al. Minimal information for studies of extracellular vesicles 2018 (MISEV2018): a position statement of the International Society for Extracellular Vesicles and update of the MISEV2014 guidelines. $J$ Extracell Vesicles. 2018; 7:1535750.

2. Zhou B, Xu K, Zheng $X$, Chen T, Wang J, Song $Y$, Shao $Y$, Zheng S. Application of exosomes as liquid biopsy in clinical diagnosis. Signal Transduct Target Ther. 2020; 5:144.

3. Bart G, Fischer D, Samoylenko A, Zhyvolozhnyi A, Stehantsev P, Miinalainen I, Kaakinen M, Nurmi T, Singh P, Kosamo S, Rannaste L, Viitala S, Hiltunen J, Vainio $S$. Characterization of nucleic acids from extracellular vesicles enriched human sweat. BMC Genomics. 2021; 22:425.

4. Lee K, Kim J, Han S, Lee D, Lee H, Yim S, Kim D. The extracellular vesicle of gut microbial Paenalcaligenes hominis is a risk factor for vagus nervemediated cognitive impairment. Microbiome. 2020; 8: 107.

5. Sun Y, Ruan J, Jiang Z, Wang L, Wang S. Extracellular vesicles: a new perspective in tumor therapy. Biomed Res Int. 2018; 2687954.

6. Robbins P, Morelli A. Regulation of immune responses by extracellular vesicles. Nat Rev Immunol. 2014; 14(3):195-208.

7. Koog L, Gandek T, Nagelkerke A. Liposomes and extracellular vesicles as drug delivery systems: a comparison of composition, pharmacokinetics, and functionalization. Adv Healthc Mater. 2021; 2100639.

8. Chang $W$, Cerione $R$, Antonyak $M$. Extracellular vesicles and their roles in cancer progression. Methods Mol Biol. 2021; 2174:143-70.

9. Samoylenko A, Kögler M, Zhyvolozhnyi A, Makieieva $O$, Bart $G$, Andoh $S$, Roussey $M$, Vainio $S$,
Hiltunen J. Time-gated Raman spectroscopy and proteomics analyses of hypoxic and normoxic renal carcinoma extracellular vesicles. Sci Rep. 2021; 11:19594.

10. Ullah S, Zhivonitko V, Samoylenko A, Zhyvolozhnyi A, Viitala S, Kankaanp S, Komulainen S, Schroder L, Vainio $S$, Telkki $V$. Identification of extracellular nanoparticle subsets by nuclear magnetic resonance. Chem Sci. 2021; 12:8311-9.

11. Chena Z, Larreginac A, Morellia A. Impact of extracellular vesicles on innate immunity. Curr Opin Organ Transplant. 2019; 24(6): 670-8.

12. Bedke J, Gauler T, Grünwald V, Hegele A, Herrmann E, Hinz S, Janssen J, Schmitz S, Schostak M, Tesch H, Zastrow $S$, Miller $K$. Systemic therapy in metastatic renal cell carcinoma. World J Urol. 2017; 35(2):179-88.

13. Pawson T. Dynamic control of signaling by modular adaptor proteins. Curr Opin Cell Biol. 2007; 19(2):112-6.

14. Schmidt MHH, Hoeller D, Yu J, Furnari FB, Cavenee WK, Dikic I, Bögler O. Alix/AIP1 antagonizes epidermal growth factor receptor downregulation by the Cbl-SETA/CIN85 complex. Mol Cell Biol. 2004;24(20):8981-93.

15. Büchse T, Horras N, Lenfert E, Krystal G, Körbel S, Schümann M, Krause E, Mikkat S, Tiedge M. CIN85 inter-acting proteins in B cells-specific role for SHIP-1. Mol Cell Proteomics. 2011; 10(10):M110.006239.

16. Lynch DK, Winata SC, Lyons RJ, Hughes WE, Lehrbach GM, Wasinger V, Corthals G, Cordwell $S$, Daly RJ. A Cortactin-CD2-associated protein (CD2AP) complex provides a novel link between epidermal growth factor receptor endocytosis and the actin cytoskeleton. $J$ Biol Chem. 2003; 278(24): 21805-13.

17. Sinha S, Hoshino D, Hong NH, Kirkbride $K C$, Grega-Larson NE, Seiki M, Tyska MJ, Weaver AM. Cortactin promotes exosome secretion by controlling branched actin dynamics. J Cell Biol. 2016; 214(2): 197-213.

18. Tossidou I, Teng B, Drobot L, Meyer-Schwesinger C, Worthmann K, Haller H, Schiffer M. CIN85/RukL is a novel binding partner of nephrin and podocin 
and mediates slit diaphragm turnover in podocytes. J Biol Chem. 2010; 85(33):25285-95.

19. Mayevska O, Shuvayeva H, Igumentseva N, Havrylov S, Basaraba O, Bobak Y, Barska M, Volod'ko N, Baranska J, Buchman V, Drobot L. Expression of adaptor protein Ruk/CIN85 isoforms in cell lines of various tissue origins and human melanoma. Exp Oncol. 2006; 28(4):275-81.

20. Ma Y, Ye F, Xie X, Zhou C, Lu W. Significance of PTPRZ1 and CIN85 expression in cervical carcinoma. Arch Gynecol Obstet. 2011; 284(3):699-704.

21. Wakasaki T, Masuda M, Niiro H, Jabbarzadeh-Tabrizi S, Noda K, Taniyama T, Komune S, Akashi K. A critical role of c-Cbl-interacting protein of $85 \mathrm{kDa}$ in the development and progression of head and neck squamous cell carcinomas through the ras-ERK pathway. Neoplasia. 2010; 12(10):789-96.

22. Yakymovych I, Yakymovych M, Zang G, Mu Y, Bergh A, Landström M, Heldin C-H. CIN85 modulates TGF $\beta$ signaling by promoting the presentation of TGF $\beta$ receptors on the cell surface. J Cell Biol. 2015; 210(2):319-32.

23. Cascio S, Finn OJ. Complex of MUC1, CIN85 and $\mathrm{Cbl}$ in Colon Cancer Progression and Metastasis. Cancers (Basel). 2015; 7(1):342-52.

24. Samoylenko A, Vynnytska-Myronovska B, Byts $N$, Kozlova N, Basaraba O, Pasichnyk G, Palyvoda K, Bobak Y, Barska M, Mayevska O, Rzhepetsky Y, Shuvayeva H, Lyzogubov V, Usenko V, Savran V, Volodko N, Buchman V, Kietzmann T, Drobot L. Increased levels of the HER1 adaptor protein Rukl/ CIN85 contribute to breast cancer malignancy. Carcinogenesis. 2012; 33(10):1976-84.

25. Valcz G, Galamb O, Krenács T, Spisák S, Kalmár A, Patai ÁV, Wichmann B, Dede K, Tulassay Z, Molnár $B$. Exosomes in colorectal carcinoma formation: ALIX under the magnifying glass. Mod Pathol. 2016; 29(8):928-38.

26. Schroeder B, Srivatsan S, Shaw A, Billadeau D, McNiven MA.CIN85 phosphorylation is essential for EGFR ubiquitination and sorting into multivesicular bodies. Mol Biol Cell. 2012; 23(18):3602-11.

27. Baietti MF, Zhang Z, Mortier E, Melchior A, Degeest $G$, Geeraerts A, Ivarsson Y, Depoortere F, Coomans C, Vermeiren E, Zimmermann P, David G.
Syndecan-syntenin-ALIX regulates the biogenesis of exosomes. Nat Cell Biol. 2012; 14(7):677-85.

28. Schmidt MHH, Dikic I, Bögler O. Src phosphorylation of Alix/AIP1 modulates its interaction with binding partners and antagonizes its activities. $J$ Biol Chem. 2005; 280(5):3414-25.

\section{Склад маркерів EVs за умов нормоксії й гіпоксії залежить від рівня експресії адаптерного протеїну Ruk/CIN85 у клітинах Renca карциноми нирки миші}

А. Ю. Живоложний, І. Р. Горак, Т. Д. Скатерна, О. В. Худякова, С. Й. Вайніо, А. А. Самойленко, Л. Б. Дробот

Мета. Виділити і охарактеризувати позаклітинні везикули (EVs), що продукуються клітинами карциноми нирки миші лінії Renca 3 різним рівнем експресії адаптерного протеїну Ruk/CIN85 за умов нормоксії й гіпоксії. Методи. Центрифугування в градієнті щільності використовували для виділення EVs 3 кондиціонованого середовища клітин Renca, культивованих за умов нормоксії й гіпоксії. Подальшу характеристику EVs проводили з використанням лазерно-кореляційного аналізу (NTA), електронної мікроскопії та Вестерн-блотингу. Результати. Істотних відмінностей у середньому розмірі EVs, утворених сублініями клітин, виявлено не було. У той же час концентрація частинок, що продукуються клітинами з надекспресією Ruk/CIN85, виявилася на порядок вищою за умов гіпоксії в порівнянні з умовами нормоксії. Було показано, що за умов нормоксії вміст як Ruk/CIN85, так i маркерів EVs (протеїнів Alix i CD81) значно збільшувався у везикулах, що продукуються клітинами Renca 3 надекспресією Ruk/CIN85, в порівнянні 3 контрольними клітинами. За умов гіпоксії вміст досліджуваних протеїнів знизився більш ніж на два порядки в EVs, що секретуються клітинами Renca 3 надекспресією адаптерного протеїну, в той час як вміст Ruk/CIN85 i CD81 збільшувався, а вміст Alix знижувався в EVs контрольних клітин. Висновки. Було продемонстровано, що адаптерний протеїн Ruk/CIN85 є новим компонентом EVs, що продукуються пухлинними клітинами, який відіграє диференційну роль в контролі складу EVs за умов нормоксії й гіпоксії. 
Кл ю ч о в і с с о в а: нирково-клітинний рак, позаклітинні везикули, екзосоми, адаптерний протеїн Ruk/ CIN85, нормоксія, гіпоксія.

\section{Состав маркеров EVs в условиях нормоксии и гипоксии зависит от уровня экспрессии адаптерного протеина Ruk/CIN85 в клетках Renca карциномы почки мыши}
А. Ю. Живоложный, И. Р. Горак, Т. Д. Скатерная, О. В. Худякова, С. Й. Вайнио, А. А. Самойленко, Л. Б. Дробот

Цель. Выделить и охарактеризовать внеклеточные везикулы (EVs), продуцируемые клетками почечной карциномы мыши линии Renca с разным уровнем экспрессии адаптерного протеина Ruk/CIN85 в условиях нормоксии и гипоксии. Методы. Центрифугирование в градиенте плотности использовали для выделения EVs из кондиционированной среды клеток Renca, культивированных в условиях нормоксии и гипоксии. Дальнейшую характеристику EVs проводили с использованием лазерно-корреляционного анализа (NTA), электронной микроскопии и Вестерн-блоттинга. Результаты. Существенных различий в среднем размере EVs, продуцируемых сублиниями клеток, обнару- жено не было. В то же время, концентрация частиц, секретируемых клетками со сверхэкспрессией Ruk/ CIN85, оказалась на порядок выше при гипоксии по сравнению с условиями нормоксии. Было показано, что в условиях нормоксии содержание как Ruk/CIN85, так и маркеров EVs (протеинов Alix и CD81) значительно увеличивалось в везикулах, продуцируемых клетками Renca со сверхэкспрессией Ruk/CIN85, по сравнению с контрольными клетками. В условиях гипоксии содержание исследуемых протеинов снизилось более чем на два порядка в EVs, секретируемых клетками Renca, со сверхэкспрессией адаптерного протеина, в то время как содержание Ruk/CIN85 и CD81 увеличилось, а содержание Alix снизилось в EVs из контрольных клеток. Выводы. Было продемонстрировано, что адаптерный протеин Ruk/CIN85 является новым компонентом EVs, продуцируемых опухолевыми клетками, который играет дифференциальную роль в контроле состава EVs в условиях нормоксии и гипоксии.

К л юч е в ы е с л о в а: почечно-клеточный рак, внеклеточные везикулы, экзосомы, адаптерный протеин Ruk/CIN85, нормоксия, гипоксия.

Received 05.09.2021 